\title{
SURVEY OF WADERS IN THE CATCHMENT AREA OF UJANI DAM, NEAR BHIGAWAN, DISTRICT PUNE (M.S.)
}

\author{
A. C. Kumbhar and B. N. Ghorpade \\ Department of Zoology and Research Centre, Shankarrao Mohite Mahavidyalaya, Akluj, District: Solapur (M.S.) \\ ac_kumbar@yahoo.co.in
}

\begin{abstract}
:
The Ujani reservoir is one of the larger water bodies in Maharashtra and created because of construction of Ujani Dam. The dam constructed across Bhima river in the period of 1964-1980. The catchment area of this water body is $14850 \mathrm{sq} \mathrm{km}$. The storage capacity of the dam is 117.25 TMC. It is located on the national highway No. 9 and $100 \mathrm{~km}$ away from Pune and $140 \mathrm{~km}$ away from Solapur. The reservoir is the major water body of Western Maharashtra and spread over in three districts namely, Solapur, Pune and Ahmednagar. Geographically it is situated on $18^{\circ}-04^{\prime}-00^{\prime \prime}$ latitude and $75^{\circ}-07^{\prime}-00^{\prime \prime}$ longitude. The average rain fall in this area is 500 to $600 \mathrm{~mm}$ per annum. The sediments are deposited with the discharge from twelve dams which are located in the crest of Sahyadri. In present research article the record of habitat of major wader birds is carried. Bird's species were recognized using binoculars. Photographs of sited birds were taken with the help of SLR digital camera. Standard field guides (Ali S, 1996 and Grimmett R, 2000) were used for acute identification and confirmation of the birds. The Ujani reservoir is an excellent habitat for waders.
\end{abstract}

Keywords: Waders, Bhima river, Ujani reservoir, Irrigated fertile land, Heritage site.

\section{Introduction:}

The waders are recognized as one of the major group of water birds these are habituated only in marshy and muddy parts of aquatic bodies. They have long legs with modifications in toes. They are with very short halux and long and slender forefingers. The ligaments and tendons of knee region are well developed and more flexible than the other birds. While feeding in the muddy parts the ligaments and tendons work more efficiently. The waders includes the members of family - Jackinidae (Jacanas), family- Caradriae (Plovers, Sandpipers, Lapwings, Curlews and Woodcocks), familyRostratulidae (Snipes), family- Recorvirostridae (Stilts) and family- Glariodae. (Cursers and Partincoles). There is very limited published reference of birds (Prakash Gole 1992).

STUDY SITE:

The Ujani reservoir is one of the larges man made water bodies in Maharashtra. It is created on a dam constructed across Bhima river in the period of 1964-1980. The catchment area of this water body is $14850 \mathrm{~km}^{2}$. The storage capacity of the dam is $117.25 \mathrm{TMC}$. It is located on the national highway No. 9. Geographically it is situated on $18^{\circ}{ }^{\circ}$ 04'- $00^{\prime \prime}$ latitude and $75^{\circ}-07^{\prime}-00^{\prime \prime}$ longitude. This location is $100 \mathrm{~km}$ away from Pune and $140 \mathrm{~km}$ away from Solapur. The reservoir is the major water body of Western Maharashtra and spread over in three districts namely, Solapur, Pune and Ahmednagar. The average rain fall in this area is 500 to $600 \mathrm{~mm}$ per annum. The sediments are deposited with the discharge from twelve dams which are located in the crest of
Sahyadri. The main tributaries of Bhima river are Velna, Ghod, Bhama, Indrayani and MulaMutha. The temperature of the site ranges between $12^{\circ} \mathrm{C}$ to $42^{\circ} \mathrm{C}$. The water body is surrounded by fertile irrigated land and natural world of heritage site for various birds.

\section{Methods:}

The bank of reservoir is characterized with silty, slightly sandy mud, slightly silty sand and clayey mud. The periodical survey for waders was done for the period of 12 months. (June -2013 to May- 2014). The bank line of reservoir with mudflats, creeks, canals and rivers were covered for the study. The survey was done between $0700 \mathrm{hrs}$ to $1800 \mathrm{hrs}$ twice in every month. The waders were observed with the help of binoculars and the photographs were taken by SLR camera with zoom lenses. Standard field guides (Ali, 1989 and Gremmet, 2000) were used for acute identification and confirmation of the wader birds. The Ujani reservoir is an excellent habitat for waders.

\section{Result and Discussion:}

In this ornithological survey 17 species of wader birds recorded with total individual number of 470 . The highest number of individual recorded was in the period of June 2013 to May- 2014.

\section{Conclusion:}

Ornithologically it was found that the Ujani reservoir is important site. Regular ornithological surveys are required in the said study site to learn more about the avifaunal researches especially the waders of this unique 
water body. In an attempt to preserve the avifaunal wealth mainly wader, the investigation made on ornithological survey in the Ujani reservoir between the period of June -2013 to
May -2014. Abundant population of waders is reported in the study area throughout the study period. The water body should be protected and developed as waders watching site.

Table. 1-List of waders recorded from the bank line of Ujani reservoir in the period of June -2013 to May -2014.

\begin{tabular}{|l|l|l|}
\hline Sr.No & Common Name & Scientific Name \\
\hline 1 & Pintail Snipe & Gallinago stenura \\
\hline 2 & Common Snipe & Gallinago gallinago \\
\hline 3 & Black-tailed Godwit & Limosa limosa \\
\hline 4 & Spotted Redshank & Tringa erythropus \\
\hline 5 & Common Redshank & Tringa tetanus \\
\hline 6 & Marsh Sandpiper & Tringa stagnatilis \\
\hline 7 & Common Greenshank & Tringa nebularia \\
\hline 8 & Common Sandpiper & Actitis hypoleucos \\
\hline 9 & Pheasant-tailed Jacana & Hydrophasianus chirurgus \\
\hline 10 & Bronze-winged Jacana & Metopidius chirugus \\
\hline 11 & Black-winged Stilt & Himantopus himantopus \\
\hline 12 & Common Ringed Plover & Charadrius hiaticula \\
\hline 13 & Little Ringed Plover & Charadrius dubius \\
\hline 14 & Kentish Plover & Charadrius alexandrinus \\
\hline 15 & Wood sandpiper & Tringa glareola \\
\hline 16 & Red-wattled Lapwing & Vanellus indicus \\
\hline 17 & Small Pratincole & Glareola lacteal \\
\hline
\end{tabular}

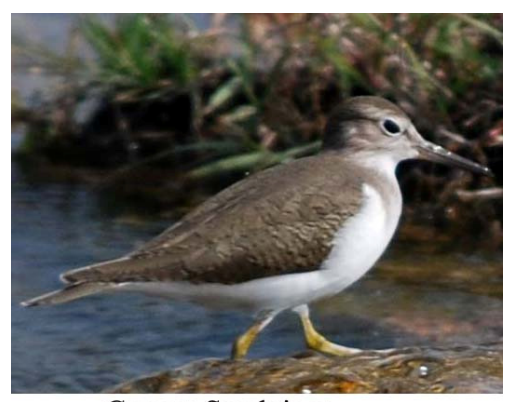

Comon Sandpiper

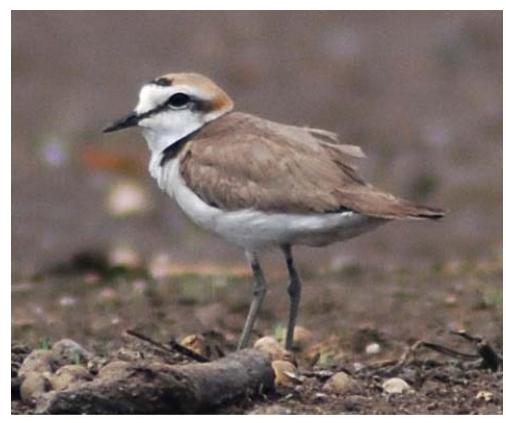

Kentish plover

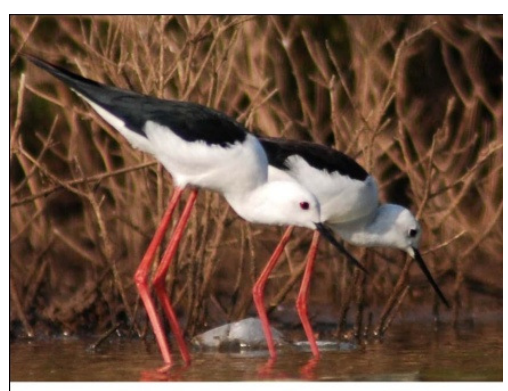

Black wingwd stilt

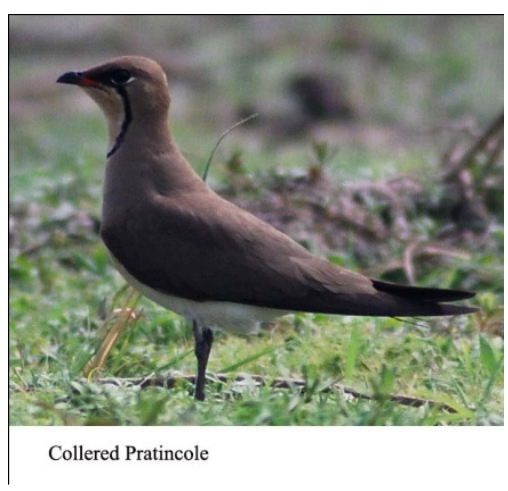

References:

Ali, S. and Ripley.S.D. (1993): .Hand book of Birds of India and Pakistan, Bombay Natural History Society, Oxford University Press. New Delhi.

Arunayan Sharma, Sathi J. P. and Tak P. C. (2008). Waders of Sagar Island, Indian Sunderbans Delta. News Letter for Bird Watchers. Vol-48, No.4

Grimmett $R$, Inskipp, $C$. and Inskipp. $T$. (1988). Birds of the Indian Subcontinent. Oxford University Press.

Finn,F. (1906): How to Know Indian Waders. Thacker Spink \& Co. Calcutta.

Peter, H. Marchant, J\& Parter, T. (1986): Shorebirds: An Identification Guide to the Waders of the World. Christoher Helm, United Kingdom. 